\title{
Perceptions of sexually transmitted diseases among teenagers
}

\author{
DM Diale, M Cur student, RAU \\ SD Roos, D Cur, Department of Nursing Science, RAU
}

\section{Abstract}

An exploratory descriptive study was undertaken, focussing on sexually transmitted diseases (STD) among teenagers. The aim of the study was to explore and describe the possible reasons for the high rate of sexually transmitted diseases in teenagers. The perceptions of teenagers and community nurses regarding sexually transmitted disease among teenagers involved in the teenage clinic in a specific predominantly black area were assessed. Twenty teenagers and five community nurses were participants in the study. Two focus group interviews were conducted with teenagers and community nurses. It can be concluded that the attitudes of community nurses may have an influence on the high rate of sexually transmitted diseases among teenagers. The knowledge of the teenagers about sexually transmitted diseases is often based on myths and misconceptions which could be intensified by the community nurse.

The recommendations made are that the education standards of all community nurses should be reviewed and adapted to meet the needs of teenagers attending the teenage health services. The policy on in-service training must be reviewed and monitored. Community nurses' intensive training on teenage health service delivery and sexually transmitted diseases services should be in accordance with the principles of Primary Health Care. Community nurses need to attend intensive courses on interpersonal skills specifically related to teenagers. Selection procedures for recruiting community nurses to attend to teenagers specifically should be researched. Teenagers should be involved in planning programs and the teenage clinic should be evaluated frequently to improve the standards. The availability of adequate teenage health services can result in a decrease in sexually transmitted diseases among teenagers.

\section{Uittreksel}

'n Verkennende beskrywende studie is onderneem, met die fokus op seksueel oordraagbare siektes onder tieners. Die doel van die studie is om die moontlike redes vir die hoë syfer van seksueel oordraagbare siektes onder tieners te verken en te beskryf. Die persepsies van tieners en gemeenskapsverpleegkundiges aangaande seksueel oordraagbare siektes onder tieners betrokke by die tienerkliniek in ' $n$ oorwegend swart gebied is ondersoek. Twintig tieners en vyf verpleegkundiges was by die studie betrokke. Twee fokus-groeponderhoude is met tieners en gemeenskapsverpleegkundiges gehou. Daar is tot die gevolgtrekking gekom dat die houding van gemeenskapsverpleegkundige ' $n$ invloed op die hoë syfer van seksueel oordraagbare siektes mag hê en dat die kennis van die tieners oor seksueel oordraagbare siektes op mites en wanopvattings berus wat deur die gemeenskapsverpleegkundige versterk kan word.

Die aanbevelings wat gedoen word, is dat die opleidingstandaarde van die gemeenskapsverpleegkundige hersien en aangepas moet word om in die behoeftes van tieners wat van hierdie gesondheidsdiens gebruik maak, te voorsien. Die beleid oor indiensopleiding moet hersien en gemonitor word. Gemeenskapsverpleegkundiges se intensiewe opleiding in dienslewering aan tieners en in seksueel oordraagbare siektes moet met die beginsels van Primêre Gesondheidsorg ooreenstem. Gemeenskapsverpleegkundiges moet intensiewe kursusse in interpersoonlike vaardighede wat spesifiek met tieners verband hou, bywoon. Die keuringsprosedures om gemeenskaps-verpleegkundiges te werf om spesifiek met tieners te werk, moet ondersoek word. Tieners moet betrokke wees by die beplanning van die programme en die kliniek vir tieners moet dikwels geëvalueer word om sodoende die standaard te verhoog. Die beskikbaarheid van toereikende gesondheidsdienste aan tieners behoort tot 'n afname in seksueel oordraagbare siektes onder tieners te lei.

\section{Introduction}

In a specific predominantly black area, sexually transmitted disease clinic statistics have indicated that there is an increased rate of sexually transmitted diseases in teenagers. Figures for 1994 obtained from the Annual health report of this local authority show a rise of more than $10 \%$, if compared to 1995 figures. Every Tuesday teenagers come to the local authority health clinic for counselling, health education, family plan- ning and the management of minor ailments. Sexually transmitted diseases have been reported as the major problem for most teenagers visiting these health clinics.

Clark (1992:767) stated that the incidence of most sexually transmitted diseases is rising and because of the sometimes devastating consequences of the disease (for example blindness in infants exposed to syphilis, gonorrhoea or herpes), it's increasing incidence is of concern to community health 
practitioners and the general public. Evidence of this concern can be seen in the fact that fifteen of the South African national health objectives for the year 2000 are related specifically to sexually transmitted diseases.

According to the National Health Policy (1991:1) in South Africa, it has been estimated that one million patients seek treatment for sexually transmitted diseases every year at local authority health clinics and private practices, and that many more are seen at hospital outpatient departments and primary health care clinics.

The World Bank has estimated the annual incidence of sexually transmitted diseases in South Africa to affect $11 \%$ of the population. Of the three thousand women who come to Baragwanath Hospital every year with incomplete abortion, three hundred are between the ages of sixteen and twenty. In this age group, the main cause of incomplete abortion is proved to be infections of sexually transmitted diseases as stipulated in the Planned Parenthood Association of South Africa (PPASA). The consequences of this will have a devastating impact on the South African economy and threaten national efforts for reconstruction and development as indicated in the Planned Parenthood Association of South Africa.

The number of teenagers diagnosed at the local authority health clinic in a specific predominantly black Metropolitan area is increasing at an alarming rate, as shown by the following statistics. Ages range between sixteen and eighteen. Total number of teenagers diagnosed: January to December 1994:350

Total number of teenagers diagnosed: January to December 1995:655

Total number of teenagers diagnosed: January to December 1996:890

The main reason for this investigation was the increase in the statistics, ill health and instability.

Sexually transmitted diseases are not only causing health problems, but have social and economic implications for everyone.

The nurse, through the health delivery system, facilitates the promotion, maintenance and restoration of individual health, the family and the community. Community nurses are being engaged in nursing activities directed toward continuing and preserving the health status of individuals, families and the community. Despite all the efforts made by community nurses, $65 \%$ of the teenagers are victims of health problems. The question arises what the perceptions of the teenager and community nurse are with regard to sexually transmitted diseases among teenagers.

The objectives of the study are to explore and describe (a) the perceptions of teenagers living in a specific predominantly black Metropolitan area regarding sexually transmitted diseases, (b) community nurses' perceptions of sexually transmitted diseases among teenagers in a specific predominantly black Metropolitan area and (c) to write guidelines on the prevention of sexually transmitted diseases among teenagers for the community nurses.

\section{Terminology}

The following terminology are defined:
-Sexually Transmitted Diseases (STD)

According to Devenish, Funnel and Greathead (1992:193), sexually transmitted diseases are diseases that are passed on by sexual contact.

\section{-Resources}

Resources in the patients' environment include assets or means of assisting the patient in facilitating his/her quest for wholeness. Resources in the patients' internal environment include physical, mental and spiritual resources. Resources in the patients' external environment include personal resources (like significant others) and professional resources (like people and organisations_Poggenpoel (1992:8).

\section{- Teenager}

A teenager in this study is defined as a boy or a girl whose age ranges from sixteen to eighteen years.

\section{-Community nurse}

The community nurse in this study refers to any registered nurse working in the clinic, irrespective of whether he/she has received specialised training in community nursing.

\section{-Perception}

Perception is defined as the individual's knowledge of sexually transmitted diseases as well as his or her opinions and attitudes about sexually transmitted diseases.

\section{Research design and method}

The design of this study is both explorative and descriptive. Focus group interviews were conducted with twenty teenagers attending the teenage clinic in a specific predominantly black Metropolitan area as well as with five community nurses working in the clinic. These interviews took place while the teenage clinic was in operation.

The study was divided into three phases: The purpose of phase 1 was to explore and describe the perceptions of teenagers about sexually transmitted diseases among teenagers. The purpose of phase 2 was to explore and describe the perceptions of community nurses about sexually transmitted diseases among teenagers and the purpose of phase 3 was to write guidelines for the community nurses on the prevention of sexually transmitted diseases among teenagers.

The sample of teenage interviewees of the study were twenty black teenagers, that is the (10) boys and ten (10) girls who had been attending the teenage clinic and five community nurses, working at the same clinic. Participation was voluntary. The sample was purposive to enhance contextuality.

Ethical consideration was maintained throughout. The research interviewer-interviewee relationship was non-threatening and emotionally safe and the human rights of the interviewees were respected. Informed consent was obtained from the interviewees in an informational letter communicating the essential information pertaining to the research.

Focus group interviews were used. The research interviewer asked one central question, namely: "What is your perception about sexually transmitted diseases among teenagers." In Zulu and Setswane the question were: " $U$ ngathini wena 
ngokugula kwe canci ku basha?

Ke eng pono ya gago ka bolwetse ba thobelano go basha?

Field notes were taken throughout the interviews regarding, non-verbal cues and practical problems (Guba and Lincoln, 1985:327). Kerlinger's (1986:477-483) method of data analysis was utilized. The researcher looked for natural variations in the data, such as variations in the focus group process, how participants responded, and how these affected the group process. The researcher, together with an independent coder met to obtain consensus on the categories identified. A protocol for data-analysis was provided for the independent coder.

Guba and Lincoln's (1985) strategy for ensuring the validity and reliability of the study was used to guide the researcher in the study. They advocated the desirability of prolonged engagement, persistent observation, triangulation and member checks which was adhered to.

\section{Results}

The main themes derived from data obtained from the teenage and community nursing respondents are grouped as follows:

Sense of belonging in teenagers, attitudes of community nurses towards teenagers, spiritual belief and morality, sources of pressure and influence, impact of the media on teenagers, responsibility for own action amongst teenagers, accessibility and acceptability of the health service.

\section{Knowledge of teenagers regarding sexually transmitted diseases}

Teenagers have some information about some aspects in sexually transmitted diseases, but the information is surrounded by myths and misconceptions, such as the one teenager that says urination immediately after sex can clear diseases. Another myth as stated by a teenage respondent is: "Sexually transmitted diseases is a disease of only dirty and promiscuous people. If you are not sleeping around you are not in danger."

The community nursés' perceptions regarding the knowledge of teenagers were inter alia: "The teenagers have a problem. They think they know; meantime they do not know anything. They have a pride within themselves. When they visit the clinic, they only expect you to provide the service and let them go." Lack of accurate information concerning both sexually transmitted diseases and the prevention makes it difficult to dismiss negative attitudes based on rumours. As indicated in Friedman (1993:96), young people themselves generally do not have adequate knowledge about sexually transmitted diseases.

\section{Sense of belonging in teenagers}

Teenagers believe in relationships. Relationships are the essential core of teenage development. Teenagers feel lonely and withdrawn if they are isolated by their peers. Teenagers collectively believe in coming together in various subgroups and evolving teenage values, attitudes and expectations. It may involve numerous patterns of acceptable or unacceptable behaviour. The community nurses inter alia expressed the following perception in this regard: "Teenagers have a problem with themselves; they do not believe in their own self. That is why all the time they are behaving in such a way to please a friend, partner or a group."

Erikson (1968:45) considers relationships to be essential to teenage development and strongly emphasize that relationships during teenage years are not primarily a sexual matter: it is the process of interpersonal development that is most important.

\section{Attitudes of community nurses towards teenagers}

The teenagers have experienced the community nurses' attitude as negative, unapproachable and with no commitment to teenagers. Community nurses have poor listening skills and behave in an inhuman way. Community nurses have poor interrelationship skills, minimal support and low esteem for the teenagers. They use jargon that teenagers do not understand. Teenagers are not treated with respect; teenagers do not perceive their interaction with community nurses as good and are not acknowledged in teenage usage of service. Poor interaction causes communication barriers and drives the teenagers to seek inaccurate knowledge from their peergroup.

The ideas were expressed in sentences like: "I no longer like the teenage clinic, I hate the nurses; they think we are kids." "Sisters are monsters they have a bad attitude, they do not treat us as human beings."

Community nurses had the following perceptions regarding the attitudes of teenagers: "They come to the clinic with a negative attitude. They always want things done their way. Teenagers are also rude. That is why we give them that kind of service. They come to the clinic to show you that they are sexually active." De Wet (1988:78-79), is of the opinion that nurses' non-verbal behaviour can, of course, also be a major aid or obstacle to his or her patients' management. The face is an exquisite instrument to communication and persuasion. The most fundamentals kinds of emotion that have clearly been associated with certain facial expressions include friendliness, anger, interest, disgust, sadness, happiness, contempt and determination.

\section{Spiritual belief and morality}

Community nurses were of the opinion that "Teenagers are affiliated to different religious beliefs though they behave totally different to what they are suppose to". Everyone has the right to freedom of conscience, religion, thought, belief and opinion as indicated in the Constitution of South Africa (Act 108 of 1996). Religious observances may be conducted at state or state aided institutions, provided that those observances follow rules made by the appropriate public authorities. Religion and morality have been indicated as dictating moral values around which teenage sexual behaviour is organised.

Rensburg (1995:369) stated that South Africa is in the position of having its people belonging to all the major religious followings of the world.

\section{Sources of pressure and influence}

According to the teenage respondents parents, teachers and 
other community leaders have had a negative impact on teenagers, especially their demands and high expectations. Teenagers have to be ideal and behave according to their parents', leaders' and society' expectations. They do not look at the teenagers as unique and different, also as human beings who have to decide the way they want to think.

Community nurse respondents are of the opinion that "The significant others can have a positive and negative impact on teenagers. The high demands we have on our teenagers are the ones that make them stubborn and decide to stay all day in the streets with friends".

Craig (1976:383) indicated that sociologically, teenagers are in a contradictory situation. On the one hand, society regards them with adulation, glorifying youth. care-freeness and leisure. On the other hand, most high schools are incredibly boring and alienating institutions, wasting their students' time in meaningless, depersonalised routines.

\section{Impact of the media on teenagers}

The media can have a positive and a negative impact on teenagers. The media can have an impact on the development of the teenagers. It is a good tool to send the message across; it can reach many people within the blink of an eye. The media has been used and is still being used positively to educate the patients, and the information revealed is mostly comprehended. The media has been regarded as a negative source that provides teenagers with romantic series that in later life tempt the teenager to imitate what he/she once observed in the media. Community nurses are aware of the positive influence that the media can have on the teenagers.

Clark (1992:771) stated that media presentations of sexual activity as desirable behaviour may have an influence on the high rate of sexually transmitted diseases. Portrayals of popular heroes and heroines as "sexy" and sexually active have fostered imitative behaviour, particularly among teenagers.

\section{Responsibility for own action among teenagers}

Teenagers are responsible and accountable for their own actions. Teenagers are aware that they have to protect themselves from being infected. Community nurses are taking the responsibility of blaming themselves as unproductive, inefficient and ineffective in the rendering of an optimal high standard of care. Community nurses' attitudes and lack of commitment may mainly have an influence on the high rate of sexually transmitted diseases among teenagers.

Rogers (1973:15) way back in 1973 mentioned that communication, as the only link between the nursing staff and black teenagers is regarded as an indispensably supportive baseline of human learning. It is the interwoven thread that holds the whole process of sex education together or could alternatively, weaken it. It is therefore essential to grasp and implement the basics of two-way communication in sex education.

\section{Accessibility and acceptability of the health service}

Teenagers respondents stated that there is geographic accessibility because the teenage clinic is situated in an area where there is lot of transport, and it is centrally situated; it is easy to reach. The service is not functionally accessible, as teenagers cannot receive appropriate care as the need arises. Clinic service is not acceptable to teenagers as it does not involve the teenagers in the planning of teenage programmes. The service does not offer confidentiality, as teenage services are not separated from the adult service.

Ideas were expressed like "we are not included in the planning of teenage programmes, we do not understand where the community nurses collect their educational topics, their topics are boring". "Teenage clinic is only once a week, it is difficult to attend on Tuesdays and there is no privacy as is not separated from adult clinic".

Community nurses were in agreement with the teenagers regarding the accessibility and acceptability of the health service to the teenagers. For example they stated that "teenagers are not actively involved during the health education sessions". Proctor (1986:16), as indicated in Curationis (Vol. 13 of December, 1990:16), says services should be conveniently available, confidential, located in a safe, familiar place and separated from adult services.

\section{Conclusions}

The study lead the author to inter alia the following conclusions:

The study has shown that even though some of the respondents were aware of sexually transmitted diseases as a problem, the information is still surrounded by myths and misconceptions. Community nurses need to conduct educational campaigns in all communities in languages that can be understood if further spread is to be prevented.

Attitudes of community nurses have been regarded as the cause of increase rate of sexually transmitted diseases and have made it difficult for the teenagers to communicate openly. Community nurses' technical language makes it difficult for the teenagers to understand.

The credibility of the community nurses is important. They need to prove that they are accountable, concerned, caring, approachable and empathetic in their profession. They need to have a listening skill at all times.

Teenagers should be considered at all times and be involved in planning programmes of their teenage clinic. Selection procedures for recruiting community nurses to attend specifically to teenagers should be considered.

\section{Guidelines for community nurses}

The guidelines focus on the following:

Improvement of teenagers' knowledge [Clark, 1984:392] It is important that the community nurse should encourage the teenagers to share their knowledge at either a formally structured or a conversational level.

An assessment of the knowledge, attitudes, concerns and behavioural needs of teenagers at whom the programme is targeted as well as of those who work with them should be incorporated in the planning phase of any lifestyle educational programme.

The selection and training of community nurses who will present a programme are of paramount importance in the successful implementation of teenagers' lifestyle educational programme.

The environment within which lifestyle education takes place is an important contribution factor to the success of a pro- 
gramme. The creation of an environment based on respect, trust and acknowledgment of differences will facilitate the growth of knowledge and the development of skills.

Strengthening the sense of belonging [Devenish, Funnel and Greathead, 1992:75; Corbett and Meyer, 1987:123]

"Partnership" is the key. Relationships are the determinants of much of what human beings do.

The community nurses should help teenagers by highlighting the positive aspects of peer pressure, rather than by continually harping on the negative.

\section{Changing of attitudes [de Wet,1988:78-79]}

The attitude and ability of the community nurses are of crucial importance in the service deliverance.

Community nurses working with teenagers should be equipped with interpersonal skills to accommodate teenagers specifically and to attend frequent in-service training, to keep them informed of the latest updates of teenage problems.

Health structures should give priority to the full utilisation of human resources by defining the technical role, supportive skills, knowledge and attitudes required for each community nurse to ensure effective primary health care.

\section{Spiritual belief and morality [Sapire, 1986:291]}

Moralising is the direct, although sometimes subtle, inculcation of the adults' values in the teenagers.

Community nurses should know the norms and values of the society and the expectations so as to transfer the knowledge to teenagers in the form of health education, and avoid the risk of choosing the less desirable values.

\section{Sources of pressure and their influence [Corbett and Meyer, 1987:125]}

Community nurses should educate parents, relatives and community leaders not to have exaggerated expectations of their teenagers.

Community nurses should explain to the parents that the teenager seeks meaning in a society increasing devoid of meaning. Teenagers want commitment and involvement in a world that often seems to them like a machine rolling on, irrespective of their endeavours.

Community nurses should strive to develop more trusting relationships between teenagers and their parents, and these will improve decision-making skills on teenagers and allow a more informed choice regarding sexual activity.

Utilisation of the media [Sapire,1990:799; Devenish, Funnel and Greathead, 1992:162]

Community nurses should:

*preview material before showing it to teenagers to assess relevance and appropriateness to that group;

*use the mass media, such as television, videos, posters, radio and other in order to popularise key prevention concepts and develop life skills education for teenagers in and out of school;

*discourage teenagers from adopting values and sexual behaviour as portrayed on television series by indicating that television is not reality based at all times, and that life is more complicated than soap operas.

\section{Accepting responsibility [Sappire, 1990:145]}

Community nurses should:

*through group work, empower teenagers with self-responsibility, confidence and self-worth when attending teenage clinic on Tuesdays;

*educate the teenagers to be accountable for their own deeds and accept the consequences thereof;

*always educate teenagers to keep an open-mind and do away with prejudice.

Service accessibility and acceptability [Friedman, 1993:72] Community nurses should:

*evaluate the teenage service frequently, and include managers in the evaluation;

*encourage interactive approaches to enable both teenagers and community nurses to participate. Community nurses should ensure that teenagers participate actively in teenage programmes;

*consider the accessibility of the service, whether geographically or functionally.

The teenage clinic should be separated from the adult services. Teenage services should be held for teenagers at suitable times and with community nurses trained to work with them. Teenage health services should undertake or support reorientation and training for all levels of existing personnel and revised programmes for the training of community health personnel.

\section{Recommendations}

It is recommended that research be done on the communication skills community nurses' needs to be able to motivate and counsel teenagers for the teenage clinic and that criteria for selection of community nurses for the teenage clinic be developed.

It is also recommended that the training of community nurses for their role as teenage educators and counsellors be re-emphasised to ensure that all community nurses can optimally fulfil their role as laid down in the community nurse's scope of practice, and continuous evaluation of the community nurses' attitudes in the provision of the service should be enhanced.

Further research should be undertaken regarding the knowledge, attitudes and educational needs of teenagers, parents and the community in the area of sexually related problems.

A comparative study including different racial groups of teenagers may also be helpful to ensure that global guidelines and recommendations can be deduced. There should be continuous ongoing education conducted by community nurses, parents and teachers to equip the teenagers with knowledge and do away with myths and misconceptions.

\section{Concluding remark}

Community nurses' and teenagers' attitudes should be the core of the service deliverance. Community nurses should 
attend an intensive course on interpersonal skills specifically regarding teenagers. Teenagers should be involved in planning programmes and the teenage clinic should be evaluated frequently to improve the standards. A selection procedure for recruiting community nurses to attend specifically to teenagers should be investigated.

\section{REFERENCES}

CLARK JM 1992: Nursing in the community. Norwalk: Appleton.

CLARK JM 1984: Community Nursing. Health Care for Today and Tommorow. Virginia:Reston.

CORBETT MA \& MEYER WJ 1987: The Adolescent and Pregnancy. Melbourne: Boston.

CRAIG GJ 1976: Human Development. Tokyo: Japan.

DE WET J 1988: The Art of Persuasive Communication. First edition. Johannesburg: Wetton.

DEVENISH C; FUNNEL, G \& GREATHEAD E 1992: Responsible Teenage Sexuality. Pretoria:Academica.

ERIKSON EH 1968: The Problem of Ego Identity. New York: Norton.

GUBA EG \& LINCOLN YS 1985: Naturalistic Inquiry. London: Sage Publications.

KERLINGER F 1988: Foundations of Behavioural Research. New York: Holt Renehart and Winston.

NATIONAL HEALTH POLICY 1991.

PATTON MQ 1980: Qualitative Evaluation Methods. Beverly Hills: Sage Publishers.

POGGENPOEL M 1992: Psychiatric Nursing. Nursing RSA 8[4] 36-37.

PROCTOR S 1990: Curationis. 13(12)

RENSBURG HJ 1995: South Africa Yearbook. Cape Town: Republic of South Africa

ROGERS EM 1973 : Communication strategies for family planning. Free Press.

SAPIRE, KE 1990: Sexuality in Family Health. $C M E, 8[8]$, 799-807

SOUTH AFRICA 1996: Constitution of South Africa, Act No. 108 of 1996, as amended. 